\title{
Variation of Particulate Matter and Its Correlation with Other Air Pollutants in Xi’an, China
}

\author{
Xin Zhang ${ }^{1 *}$, Yuesheng Fan ${ }^{1 * *}$, Wanqing Yu ${ }^{1}$, Huan Wang ${ }^{1}$, Xiaoli Zhang ${ }^{2}$

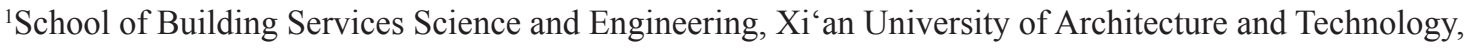 \\ No.13 Yanta Road, Xi'an, Shaanxi, China, 710055 \\ ${ }^{2}$ Xi'an Tianhua Architectural Design Co., Ltd, Xi'an, Shaanxi, China, 710000
}

Received: 28 August 2020

Accepted: 2 November 2020

\begin{abstract}
In recent years, the high concentration of air pollutants has seriously affected people's daily life. So, it is important and necessary to know the spreading $\mathrm{PM}_{2.5}$ concentration and its correlation with other pollutants. The data presented in this paper was received from 13 monitoring stations by a typical northern city of Xi'an in China for the whole year of 2017. The concentration distribution of $\mathrm{PM}_{2.5}$ and its variations with the season, month and day were analyzed. Also the average correlation between $\mathrm{PM}_{2.5}$ and $\mathrm{CO}, \mathrm{SO}_{2}, \mathrm{NO}_{2}, \mathrm{O}_{3}$ and $\mathrm{PM}_{10}$ was studied. The results showed concentrating $\mathrm{PM}_{2.5}$ was consistent with the seasonal, monthly and daily trends. The concentration of $\mathrm{PM}_{2.5}$ showed a low in summer and autumn. While the concentration of $\mathrm{PM}_{2.5}$ was higher in spring and winter, and the highest concentration was in winter. The daily variation distribution of $\mathrm{PM}_{2.5}$ showed a double-peak variation characteristic. The concentration of $\mathrm{PM}_{2.5}$ reached a peak between 8:00-9:00 in the morning and 22:00-23:00 in the evening. Particles of Xi'an in atmospheric were mainly fine particles. There was a strong correlation between $\mathrm{PM}_{2.5}$ and $\mathrm{CO}, \mathrm{SO}_{2}, \mathrm{NO}_{2}, \mathrm{PM}_{10}$, but a negative correlation between $\mathrm{PM}_{2.5}$ and $\mathrm{O}_{3}$. A multivariate linear regression model with the pollutant concentration of $\mathrm{CO}, \mathrm{SO}_{2}, \mathrm{NO}_{2}$ and $\mathrm{PM}_{10}$ was established. This study helps to understand the distribution of $\mathrm{PM}_{2.5}$ and its correlation with other pollutants of Xi'an, and further supplying important support for the targeted controlling approach of fog and haze.
\end{abstract}

Keywords: correlation, concentration distribution, other pollutants, $\mathrm{PM}_{2.5}$, variation

\section{Introduction}

With improved living conditions, people gradually pay more and more attention to the problems which were caused by air pollution [1]. The concentrations of particulates and gassy pollutants in the atmosphere were all seriously exceeded. Such as $\mathrm{PM}_{2.5}, \mathrm{PM}_{10}$, sulfur

*e-mail: 2601084634@qq.com

**e-mail: fanyuesheng@xauat.edu.cn dioxide $\left(\mathrm{SO}_{2}\right)$, nitrogen dioxide $\left(\mathrm{NO}_{2}\right)$, carbon monoxide $(\mathrm{CO})$, and ozone $\left(\mathrm{O}_{3}\right)$ [2]. They would not only lead to a serious decline in atmospheric visibility, but also they would cause many problems to people's travel and transport at the same time [3]. $\mathrm{PM}_{25}$ was usually referred to as particulate with an average aerodynamic diameter of less than $2.5 \mu \mathrm{m}$, and they did not settle automatically [4]. $\mathrm{PM}_{2.5}$ was more likely to carry more viruses or bacteria with its small particle sizes and large specific surface area. It would bring different degrees of harm to human health, even death [5-7]. 


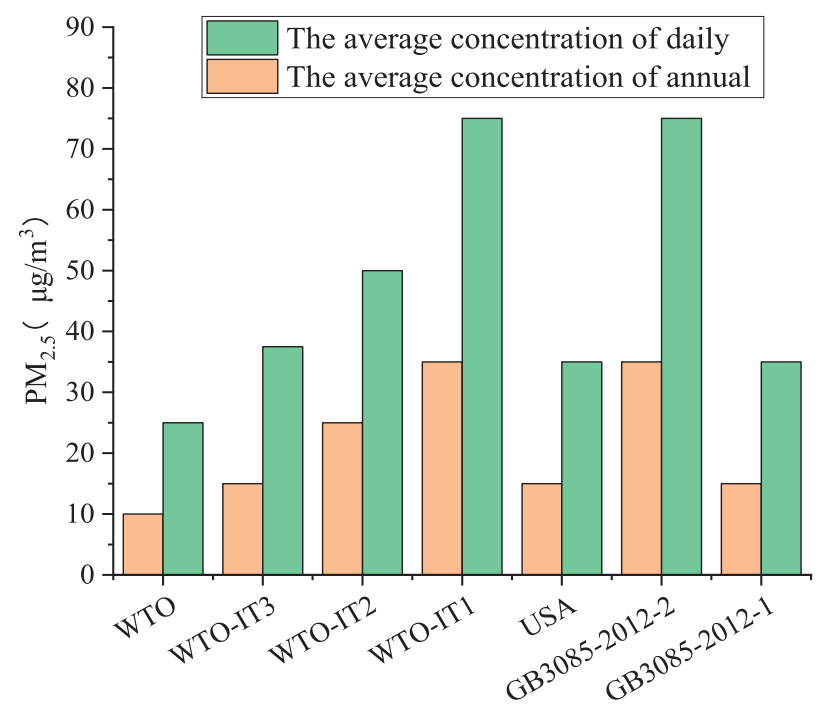

Fig. 1. Limit concentrations for $\mathrm{PM}_{2.5}$ in each standard.

Therefore, all countries and related organizations had been adopted many policies and standards to reduce the concentration of atmospheric particulate matters now [8-12]. Most developed countries been updated and improved the relevant standards now. $\mathrm{PM}_{2.5}$ was taken into the latest control target, and the limit concentrations for $\mathrm{PM}_{2.5}$ were shown in Fig. 1.

Besides limited of the daily average concentration and annual average concentration for $\mathrm{PM}_{25}$, WHO also showed three transition period target values, which would provide phased targets for countries or regions. The limit of daily average concentration of $\mathrm{PM}_{2.5}$ in developed countries was consistent $\left(25-35 \mu \mathrm{g} / \mathrm{m}^{3}\right)$, which was lower than the limit value of developing countries. The average daily concentration of $\mathrm{PM}_{25}$ was as a recommended signal and it was not compulsory [13]. The daily average concentrations were 35 and $75 \mu \mathrm{g} / \mathrm{m}^{3}$ for $\mathrm{PM}_{2.5}, 50$ and $150 \mu \mathrm{g} / \mathrm{m}^{3}$ for $\mathrm{PM}_{10}$ in Chinese standard, respectively [12].

The study of pollution characteristics and sources for $\mathrm{PM}_{2.5}$ in atmosphere also gradually becamethe focus of researchers at different countries. Some results had been achieved, and the main focus were on composing particulate matters [14], the limits of the standards [15], regional studies [16], human health and the correlation between particulate matters and other pollutants [17]. In addition, more scholars were also focusing on the research and development of new air filter materials to control the concentration of particulate matter $[18$, 19]. Also some types of corresponding measures and research were carried out to solve the existing environmental pollution problems [20-25]. For example, plants could reduce many pollutants such as carbon monoxide, particles $[20,21]$, and they also could change the climate on the environment as well as urban area [22]. Furthermore, the plants could reduce the stress and negative feelings to improve the effectiveness of work [23-25].
However, there were few studies on the concentration distribution characteristics of $\mathrm{PM}_{2.5}$ in different timescales and correlating other major pollutants in the atmosphere. The research on the current domestic was only part of the region. For example, Tianjin [26], Shanghai [27], Guangzhou [28], Xi'an [14]. But there were great distinctions in different regions of China, and the characteristics of pollutants would also change every year, which would lead to more complicated distribution and source of $\mathrm{PM}_{25}$. There was why spreading $\mathrm{PM}_{2.5}$ concentrations in different regions was different [29]. So, the typical regional research on the frequent smog in the central and western regions was even more lacking.

Xi'an was selected as an example in this paper, which was the typical city of northern China, and it is located at east longitude from $107.40^{\circ} \sim 109.49^{\circ}$ and north latitude $33.42^{\circ} \sim 34.45^{\circ}$. The data was received form 13 monitoring stations of Xi'an for the whole year of 2017. The aim of the study was to provide the detailed data on pollutant concentrations, and the concentration distribution of $\mathrm{PM}_{2.5}$ and its correlation with other pollution were taken into analysis. It would help to explore the causes of $\mathrm{PM}_{2.5}$ pollution and its main sources.

\section{Methods}

The data was collected from January 31, 2017 to December 31, 2017 in this paper, and they was gathered from the national urban air quality real-time publishing platform. Such as the average concentration values of $\mathrm{O}_{3}$, $\mathrm{CO}, \mathrm{SO}_{2}, \mathrm{NO}_{2}, \mathrm{PM}_{10}$ and $\mathrm{PM}_{2.5}$ were all collected from the weather forecast network (http://www.tianqihoubao. com/aqi/xian) every day. The hourly concentration values of six kinds of pollutants in 13 monitoring stations in Xi'an released by the weather network (http://www.tianqi.com/air/xian.html). According to the air quality index [12], the average value of each pollutant after the summary of each mocnitoring point was calculated. In addition, GRIMM1.109 portable aerosol particle size spectrometer was used to measure the concentration of particles in the atmosphere. Measuring range was $0.1 \sim 100.000 \mu \mathrm{g} / \mathrm{m}^{3}$. Counting range was $2000000 \mathrm{P} / \mathrm{L}$, and 31 particle size channels were divided between $0.25 \sim 32 \mu \mathrm{m}$. Repeatability was $5 \%$. To ensure the truth of the data statistics, some of Chinese standards were referenced to make sure the data more effectively [12, 30, 31].

Fig. 2 showed the annual average concentrations of $\mathrm{PM}_{25}$ in 31 tested cities in China was between 18.4 and $81.0 \mu \mathrm{g} / \mathrm{m}^{3}$. The city with the smallest average concentration of $\mathrm{PM}_{25}$ was Lasa, and the largest city was Shijiazhuang. The difference between them was $62.6 \mu \mathrm{g} / \mathrm{m}^{3}$. The highest average daily concentration of $\mathrm{PM}_{2.5}$ was Xi'an, while the lowest average daily concentration of $\mathrm{PM}_{2.5}$ was Lasa, and the city with the daily average concentration of $\mathrm{PM}_{25}$ meeting 


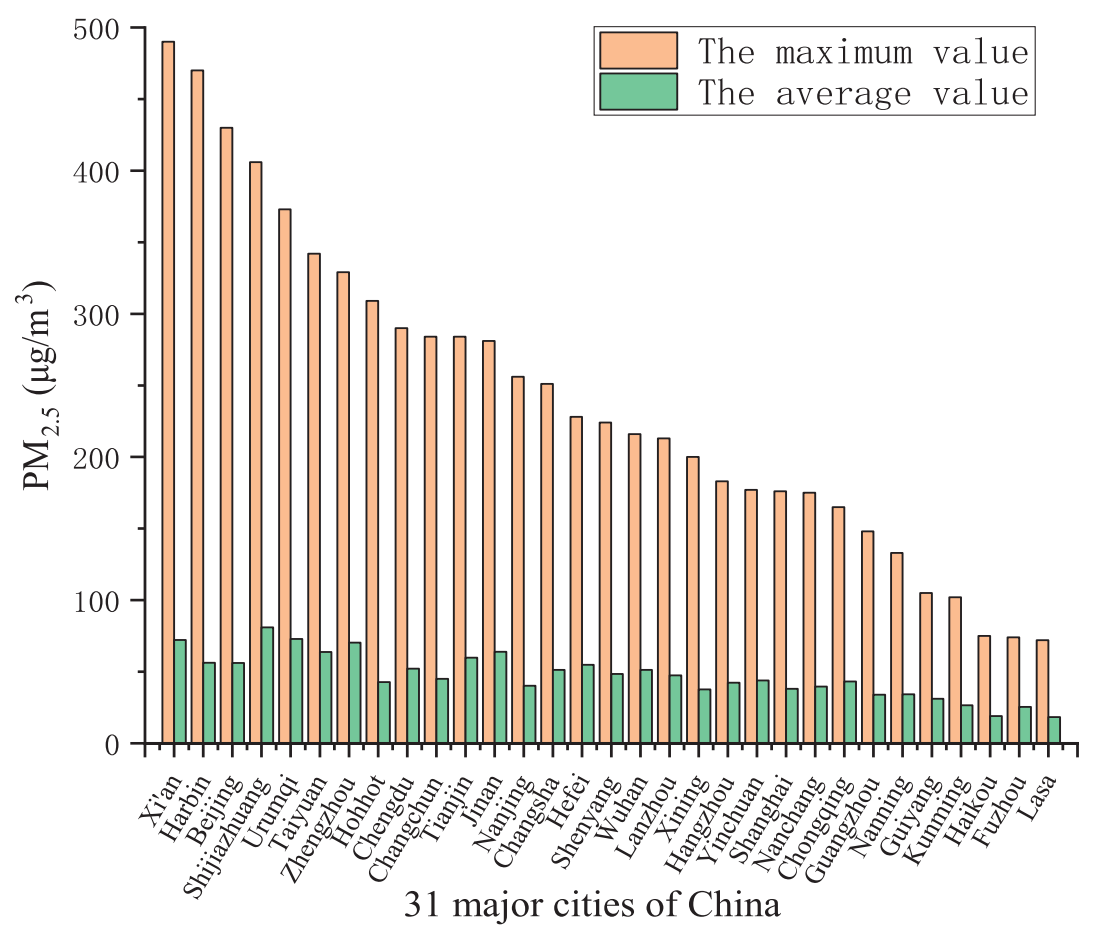

Fig. 2. Annual average concentration of $\mathrm{PM}_{2.5}$ in part cities of China.

the national secondary standard was only Lasa [12]. Therefore, the study of $\mathrm{PM}_{25}$ in atmosphere of Xi'an was more representative.

\section{Results and Discussion}

\section{Quarterly Variation of $\mathrm{PM}_{2.5}$ Concentration}

The data of five typical monitoring stations in Xi'an (Caotan, Fang Zhicheng, high voltage switch factory, Xiaozhai and Chang'an district) in 13 monitoring stations was selected in this paper. The statistics were divided into four seasons: spring, summer, autumn and winter. The spring was March to May, the summer was June to August, the autumn was September to November, and the winter was December to February [32]. The average concentration of $\mathrm{PM}_{2.5}$ in different seasons was shown in Fig. 3.

Fig. 3 showed the concentrations of $\mathrm{PM}_{2.5}$ in different seasons showed different trends. The concentrations of $\mathrm{PM}_{2.5}$ which were measured by different monitoring stations in the same season were roughly same. The concentrations of $\mathrm{PM}_{25}$ were low in summer (JuneAugust) and autumn (September-November). The concentrations of $\mathrm{PM}_{2.5}$ were high in spring (March-May) and winter (December-February). The highest was in winter, and about $140 \mu \mathrm{g} / \mathrm{m}^{3} \sim 158 \mu \mathrm{g} / \mathrm{m}^{3}$. The lowest was in summer, and about $30.0 \mu \mathrm{g} / \mathrm{m}^{3} \sim 37.5 \mu \mathrm{g} / \mathrm{m}^{3}$. The seasonal average concentration was followed: winter $>$ autumn $>$ spring $>$ summer. The concentrations of $\mathrm{PM}_{25}$ in winter was about 2.22 2.97 times higher than spring, about 3.74 5.27 times higher than summer, about 2.11 2.56 times higher than autumn. It also showed the concentration of $\mathrm{PM}_{25}$ did not exceed the national secondary standard only Xiaozhai $\left(29.6 \mu \mathrm{g} / \mathrm{m}^{3}\right)$ and Changan District $\left(30.2 \mu \mathrm{g} / \mathrm{m}^{3}\right)$ in summer, while the other seasons were exceeded the secondary standard [12]. The reasons were affected by heating in winter, and large of particulate matters were produced by burning of fossil fuels. In addition, it was not conducive to spread of pollutants under the low air pressure in winter, while eroding rainwater also played a certain role in elimination in summer [32]. The season in winter had a greater impact on $\mathrm{PM}_{2.5}$, while the season in summer had a much smaller impact on $\mathrm{PM}_{2.5}$. It was consistent with the conclusions given in reference [26].

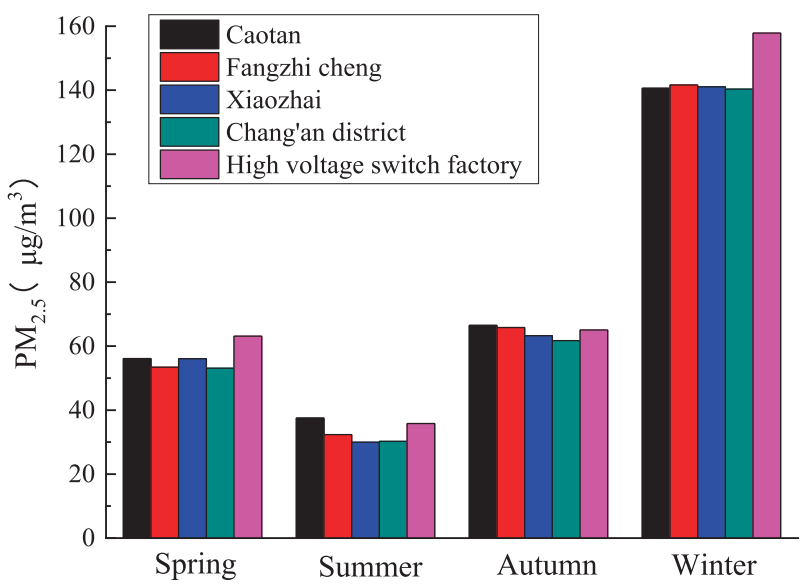

Fig. 3. Quarterly concentration characteristics of $\mathrm{PM}_{2.5}$. 


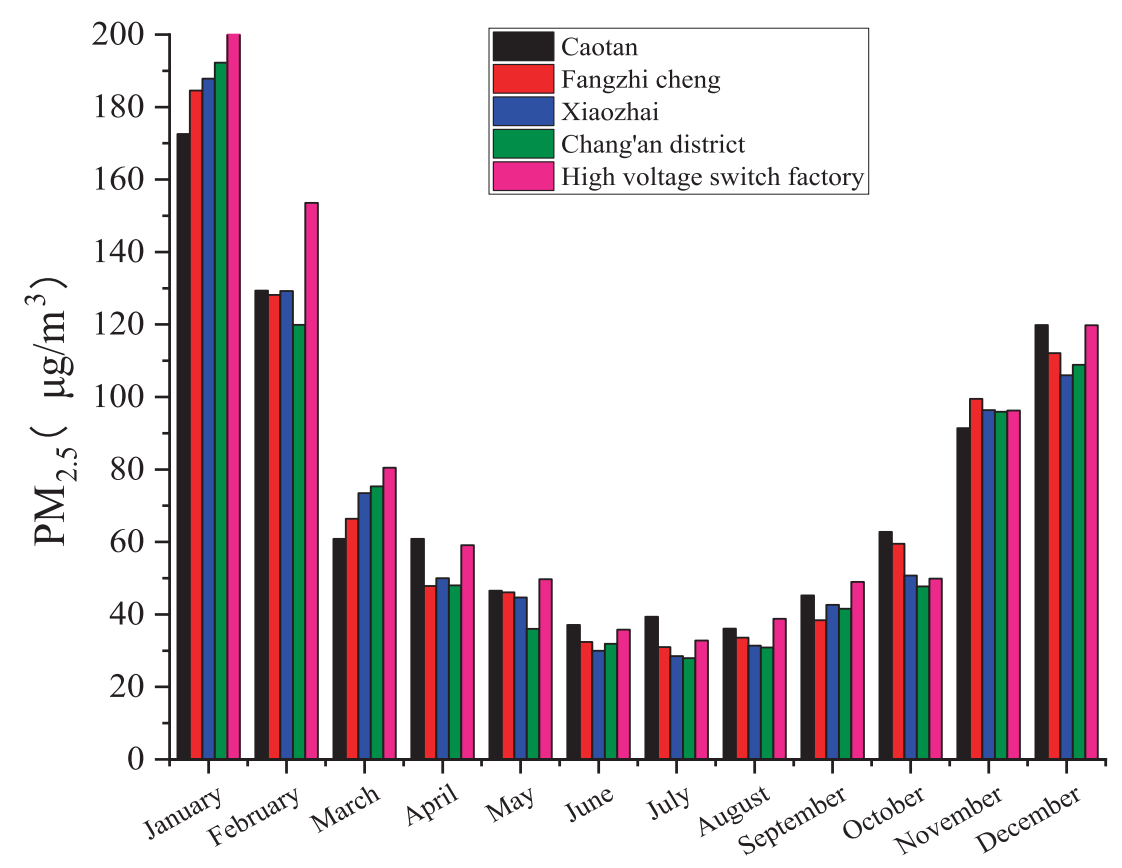

Fig. 4. Monthly concentration characteristics of $\mathrm{PM}_{2.5}$.

\section{Monthly Variation of $\mathrm{PM}_{2.5}$ Concentration}

The average concentration of $\mathrm{PM}_{2.5}$ in five environmental monitoring stations was shown in Fig. 4.

Fig. 4 showed the annual trends of $\mathrm{PM}_{2.5}$ concentration which were given by the five regional monitoring stations were roughly the same, and they were not much different. The annual average values of $\mathrm{PM}_{25}$ in Caotan, Fangzhi Cheng, Xiaozhai, Chang'an district and High voltage switch factory were $68.8 \mu \mathrm{g} / \mathrm{m}^{3}, 71.8 \mu \mathrm{g} / \mathrm{m}^{3}, 71.5 \mu \mathrm{g} / \mathrm{m}^{3}, 69.4 \mu \mathrm{g} / \mathrm{m}^{3}$ and $79.2 \mu \mathrm{g} / \mathrm{m}^{3}$, respectively. They were higher than the standard which was given the secondary standard limit $\left(35 \mu \mathrm{g} / \mathrm{m}^{3}\right)$ [12]. They were 1.97 times, 2.05 times, 2.04 times, 1.98 times and 2.26 times higher than the standard, respectively. The monthly distribution of $\mathrm{PM}_{2.5}$ showed a trend of U-shaped, and the average monthly concentration of $\mathrm{PM}_{2.5}$ was the highest in January, while the average monthly concentration of $\mathrm{PM}_{2.5}$ was the lowest in July. The average monthly concentration of $\mathrm{PM}_{2.5}$ was as followed: January $>$ February $>$ December $>$ November $>$ March $>$ October $>$ April $>$ May $>$ September $>$ August $>$ June $>$ July. The main reason was the level of particulate matter increased because of the need for heating in winter [14]. They were not conducive to spread pollutants under the low temperature in winter [32].

\section{Daily Variation of $\mathrm{PM}_{2.5}$ Concentration}

The average daily concentration of $\mathrm{PM}_{2.5}$ was from 0:00 to 23:00 on February 1, 2017, and the variation of $\mathrm{PM}_{2.5}$ at different time of the day was shown in Fig. 5.

Fig. 5 showed the daily average concentration of $\mathrm{PM}_{25}$ in the five monitoring stations varied from 99 to
$226 \mu \mathrm{g} / \mathrm{m}^{3}$. All of them were exceed the secondary limit [12]. The concentration distribution of $\mathrm{PM}_{2.5}$ was showed a double peak variation characteristic. Concentrating $\mathrm{PM}_{2.5}$ changed at different time of the day, and it showed that human activity had a significant effect on concentrations of $\mathrm{PM}_{2.5}$ [14]. $\mathrm{PM}_{2.5}$ concentration was the lowest at 0:00, the activities of human were low, while the outdoor environment was better. With the increase of people's activities in the morning, the sources of particulate matters also increased. The concentration of $\mathrm{PM}_{2.5}$ reached a peak between 8:00 and 9:00, while there were the high peak of people's travel at that time, and the pollutant emissions also reached the peak of the day. With the passage of time, the concentration of $\mathrm{PM}_{2.5}$ gradually decreased, which was

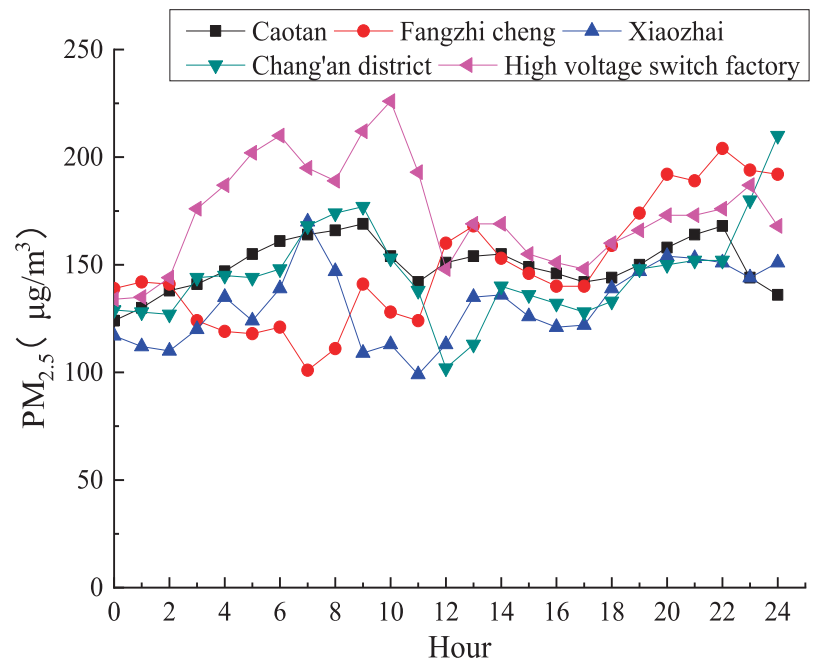

Fig. 5. Daily concentration characteristics of $\mathrm{PM}_{2.5}$. 


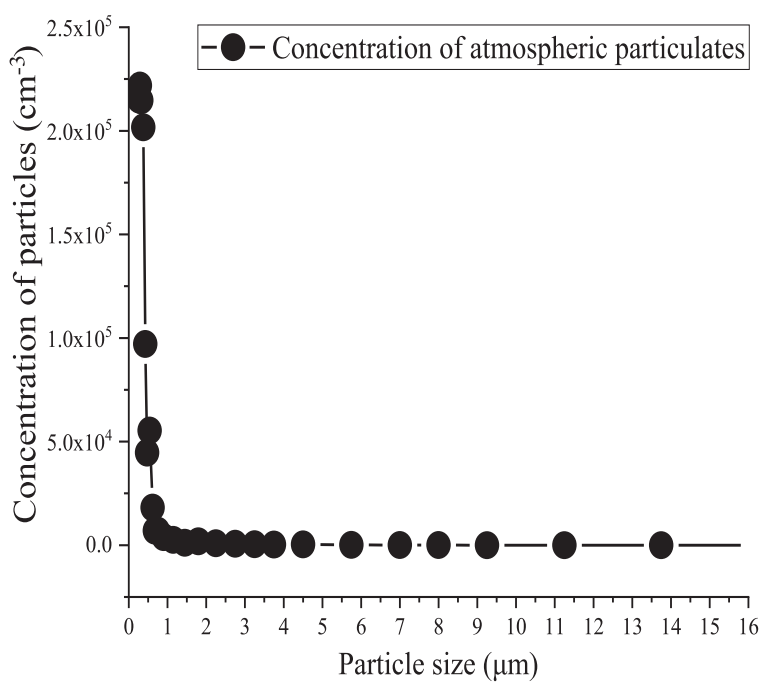

Fig. 6. Concentration distribution of particulate matters in atmospheric.

caused by strong solar radiation in the afternoon, high atmospheric temperature, and strong turbulent exchange and vertical diffusion between gas [14]. Concentrating $\mathrm{PM}_{2.5}$ reached peaks between 22:00 and 23:00, which was caused by people's everyday activities. The difference in hourly concentration variation which was given by different monitoring stations was related to the locations of monitoring stations and the make-up of the industrial chain [18].

\section{Variation of Different Particle Sizes in Atmospheric}

Fig. 6 showed the average of the test concentrations in 8 different months of the whole year in 2017 for analysis. Particle size of 0 to $0.54 \mu \mathrm{m}$ accounted for $95.9 \%$. Particle size of 0.54 to $1.0 \mu \mathrm{m}$ accounted for $3.29 \%$. With a particle size of 1.0 to $2.5 \mu \mathrm{m}$ accounted for $0.591 \%$. Particles above $2.5 \mu \mathrm{m}$ accounted for $0.184 \%$. Particle sizes of $0-2.5 \mu \mathrm{m}$ accounted for most of the atmosphere during the testing, accounting for $99.8 \%$. Particle sizes of 0-1.0 $\mu \mathrm{m}$ accounted for more than $99.2 \%$. Particles of Xi'an in atmospheric were mainly fine particles. This conclusion was consistent with the literature [33], which were easy to enter the human respiratory tract and lungs, and they were seriously harmful to human health [4].

\section{Correlation between $\mathrm{PM}_{2.5}$ and Other Major Pollutants}

Xiao Zhai was located in the southern suburbs of $\mathrm{Xi}$ 'an, and it has a large population and prosperous business [14]. Therefore, it was more representative as the selected point to study. The date was selected from January 1 to December 31 in 2017. The average correlation between $\mathrm{PM}_{2.5}$ and $\mathrm{CO}, \mathrm{SO}_{2}, \mathrm{NO}_{2}, \mathrm{O}_{3}$ and $\mathrm{PM}_{10}$ was studied.
Fig. 7a) showed there was a consistent change of the trend between the daily average concentration value of $\mathrm{PM}_{2.5}$ and $\mathrm{PM}_{10}$. The annual average value of $\mathrm{PM}_{2.5}$ was $71.5 \mu \mathrm{g} / \mathrm{m}^{3}$, while the annual average value of $\mathrm{PM}_{10}$ was $137.8 \mu \mathrm{g} / \mathrm{m}^{3}$. The highest daily average concentration of $\mathrm{PM}_{10}$ could reach $806 \mu \mathrm{g} / \mathrm{m}^{3}$, while the highest daily average concentration of $\mathrm{PM}_{2.5}$ could reach $561 \mu \mathrm{g} / \mathrm{m}^{3}$. This showed the decrease of $\mathrm{PM}_{10}$ emissions was critical for reducing pollution with PM [1]. The correlation coefficient between $\mathrm{PM}_{2.5}$ and $\mathrm{PM}_{10}$ was 0.917 , which was considered to be highly relevant.

Fig. 7b) showed the annual average value of $\mathrm{PM}_{2.5}$ was $71.5 \mu \mathrm{g} / \mathrm{m}^{3}$, while the annual average value of CO was $1.43 \mathrm{mg} / \mathrm{m}^{3}$. The highest daily average concentration of $\mathrm{CO}$ could reach $5.5 \mathrm{mg} / \mathrm{m}^{3}$, while the highest daily average concentration of $\mathrm{PM}_{2.5}$ could reach $561 \mu \mathrm{g} / \mathrm{m}^{3}$. Related research showed that when the concentration of $\mathrm{CO}$ in the atmosphere was exceeded $35 \mathrm{ppm}$, it would cause serious harm to the human body where they were located [34]. The correlation coefficient between $\mathrm{PM}_{2.5}$ and $\mathrm{CO}$ was 0.871 , which was considered to be highly relevant.

Fig. 7c) showed the annual average value of $\mathrm{PM}_{2.5}$ was $71.5 \mu \mathrm{g} / \mathrm{m}^{3}$, while the annual average value of $\mathrm{NO}_{2}^{2.5}$ was $62.0 \mu \mathrm{g} / \mathrm{m}^{3}$. The highest daily average concentration of $\mathrm{NO}_{2}$ could reach $155 \mu \mathrm{g} / \mathrm{m}^{3}$, while the highest daily average concentration of $\mathrm{PM}_{25}$ could reach $485 \mu \mathrm{g} / \mathrm{m}^{3}$. This was because consuming fossil fuel in winter was large so the air pollutions of outdoor were large [35]. The correlation coefficient between $\mathrm{PM}_{2.5}$ and $\mathrm{NO}_{2}$ was 0.732 , which was considered to be highly correlated.

Fig. 7d) showed the annual average value of $\mathrm{PM}_{2.5}$ was $71.5 \mu \mathrm{g} / \mathrm{m}^{3}$, while the annual average value of $\mathrm{SO}_{2}$ was $17.4 \mu \mathrm{g} / \mathrm{m}^{3}$. The highest daily average concentration of $\mathrm{SO}_{2}$ could reach $54.0 \mu \mathrm{g} / \mathrm{m}^{3}$, while the highest daily average concentration of $\mathrm{PM}_{2.5}$ could reach $108 \mu \mathrm{g} / \mathrm{m}^{3}$. Related research showed that $\mathrm{SO}_{2}$ was the main gassy pollutant to form of $\mathrm{PM}_{2.5}$ [36]. The correlation coefficient between $\mathrm{PM}_{2.5}$ and $\mathrm{SO}_{2}$ was 0.694 , which was considered to be moderately correlated. The correlation between the concentration of $\mathrm{PM}_{2.5}$ and $\mathrm{SO}_{2}$ was seasonally different. The correlation was better in spring and winter, while the correlation was less relevant in summer and autumn.

Fig. 7e) showed there was a different change of the trend between the daily average concentration value of $\mathrm{PM}_{2.5}$ and $\mathrm{O}_{3}$. The annual average value of $\mathrm{PM}_{2.5}$ was $71.5 \mu \mathrm{g} / \mathrm{m}^{3}$, while the annual average value of $\mathrm{O}_{3}$ was $51.7 \mu \mathrm{g} / \mathrm{m}^{3}$. The highest daily average concentration of $\mathrm{O}_{3}$ could reach $163 \mu \mathrm{g} / \mathrm{m}^{3}$, while the highest daily average concentration of $\mathrm{PM}_{2.5}$ could reach $40.2 \mu \mathrm{g} / \mathrm{m}^{3}$. The average concentration of $\mathrm{O}_{3}$ in summer was the highest. It was opposite to the change with the average concentration of $\mathrm{PM}_{2.5}$. Related research showed that if ozone was increased in the troposphere, it would have a serious impact on the environment and human health [37]. The correlation coefficient between $\mathrm{PM}_{2.5}$ and $\mathrm{O}_{3}$ was -0.449 , which was considered to be a negative correlation. 

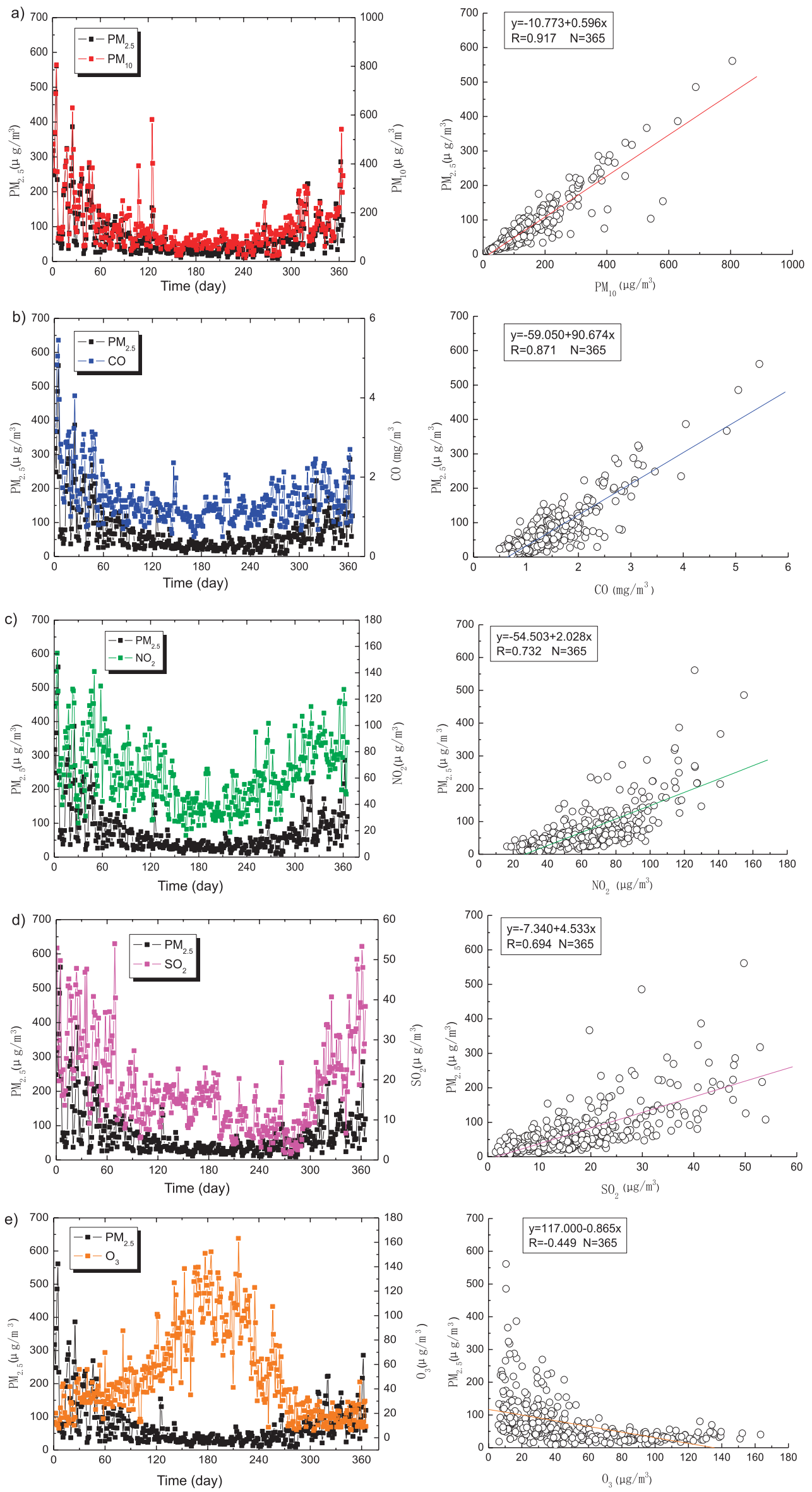

Fig. 7. Correlativity between $\mathrm{PM}_{2.5}$ and other major pollutants: a) Correlativity between $\mathrm{PM}_{2.5}$ and $\mathrm{PM}_{10}$, b) Correlativity between $\mathrm{PM}_{2.5}$ and $\mathrm{CO}$, c) Correlativity between $\mathrm{PM}_{2.5}$ and $\mathrm{NO}_{2}$, d) Correlativity between $\mathrm{PM}_{2.5}$ and $\mathrm{SO}_{2}$, e) Correlativity between $\mathrm{PM}_{2.5}$ and $\mathrm{O}_{3}$. 


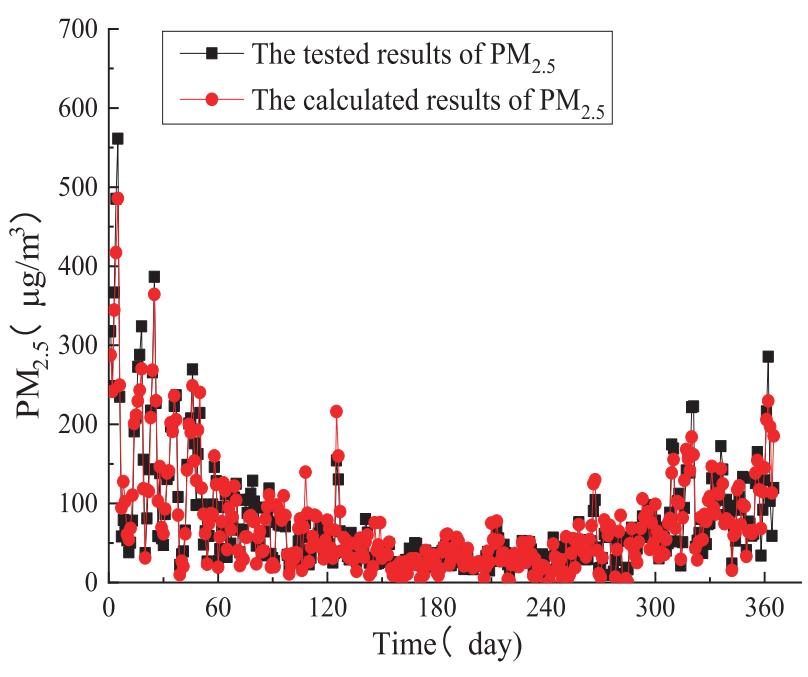

Fig. 8. Comparison of calculated and tested results of $\mathrm{PM}_{2.5}$.

\section{Multiple Linear Regression Equations for $\mathrm{PM}_{25}$ and Other Pollutants}

The correlation coefficients between $\mathrm{PM}_{2.5}$ and each pollutant was as follows: $0.917>0.871>0.732>0.694$. The corresponding pollutants affecting the magnitude of $\mathrm{PM}_{2.5}$ were: $\mathrm{PM}_{10}>\mathrm{CO}>\mathrm{NO}_{2}>\mathrm{SO}_{2}$. Therefore, among them the most relevant pollutant was $\mathrm{PM}_{10}$. A multiple linear regression model was established by the software Eviews as follows (1).

$$
Y=\beta_{0}+\beta_{1} X_{\mathrm{CO}}+\beta_{2} X_{\mathrm{NO}_{2}}+\beta_{3} X_{\mathrm{SO}_{2}}+\beta_{4} X_{P M_{10}}
$$

...where: $\mathrm{Y}, \mathrm{X}_{\mathrm{CO}}, \mathrm{X}_{\mathrm{NO}_{2}}, \mathrm{X}_{\mathrm{SO}_{2}}$, and $\mathrm{X}_{\mathrm{PM}_{10}}$ were the average daily concentration values of $\mathrm{PM}_{2.5}, \mathrm{CO}, \mathrm{NO}_{2}, \mathrm{SO}_{2}$, and $\mathrm{PM}_{10}$, respectively.

The final formula was as follows (2):

$$
\begin{gathered}
\mathrm{Y}=37.5 \mathrm{X}_{\mathrm{CO}}+0.107 \mathrm{X}_{\mathrm{NO}_{2}}+0.763 \mathrm{X}_{\mathrm{SO}_{2}} \\
+0.348 \mathrm{X}_{\mathrm{PM}_{10}}-50.7
\end{gathered}
$$

The correlation coefficient $\mathrm{R}$ was 0.915 , and the decision coefficient $\mathrm{R}^{2}$ was 0.914 . From the point of decision coefficient, the regression equation was obvious.

The daily average concentrations of $\mathrm{CO}, \mathrm{SO}_{2}$, $\mathrm{NO}_{2}$ and $\mathrm{PM}_{10}$ were substituted into the formula (2). Compared with the results between the tested and calculated of the $\mathrm{PM}_{25}$ were shown in Fig. 8. It showed the prediction effect was good, and the overall trend was still consistent with the tested results. However, there was a large variation of $\mathrm{PM}_{2.5}$ in spring. It was a certain deviation in the prediction effect, but the overall still had a good agreement. So it could be considered the daily average concentration of $\mathrm{PM}_{2.5}$ which was obtained by the multiple linear regression equation (2) could be effectively predicted and monitored.

\section{Conclusions}

The data was based on five typical monitoring stations of Xi'an in China for the whole year of 2017 in this paper. The concentration distribution of $\mathrm{PM}_{2.5}$ and its correlation with other air pollutants was analyzed, and the conclusions were as follows:

1. The concentration value of $\mathrm{PM}_{2.5}$ was consistent with the seasonal, monthly and daily mean trends. It showed a low $\mathrm{PM}_{2,5}$ concentration in summer (JuneAugust) and autumn (September-November), while the concentrations of $\mathrm{PM}_{2.5}$ were higher in spring (MarchMay) and winter (December-February), and the highest were in winter.

2. Variation distribution of $\mathrm{PM}_{2.5}$ concentration showed a double-peak variation characteristic. The concentration of $\mathrm{PM}_{2.5}$ reached a peak between 8:00-9:00 in the morning and 22:00-23:00 in the evening, and the particles of Xi'an were mainly fine particles.

3. There was a strong correlation between $\mathrm{PM}_{2.5}$ and $\mathrm{CO}, \mathrm{SO}_{2}, \mathrm{NO}_{2}, \mathrm{PM}_{10}\left(\mathrm{PM}_{2.5} / \mathrm{CO} \mathrm{r}=0.871, \mathrm{PM}_{2.5} / \mathrm{SO}_{2}\right.$ $\left.\mathrm{r}=0.694, \mathrm{PM}_{2.5} / \mathrm{NO}_{2} \mathrm{r}=0.932, \mathrm{PM}_{2.5} / \mathrm{PM}_{10} \mathrm{r}=0.917\right)$. But a negative correlation between $\mathrm{PM}_{2.5}$ and $\mathrm{O}_{3}$ $\left(\mathrm{PM}_{2.5} / \mathrm{O}_{3} \mathrm{r}=-0.449\right)$.

4. A multivariate linear regression model with the pollutant concentration of $\mathrm{CO}, \mathrm{SO}_{2}, \mathrm{NO}_{2}$ and $\mathrm{PM}_{10}$ as independent was established as follows: $\mathrm{Y}=37.5 \mathrm{X}_{\mathrm{CO}}$ $+0.107 \mathrm{X}_{\mathrm{NO}_{2}}+0.763 \mathrm{X}_{\mathrm{SO}_{2}}+0.348 \mathrm{X}_{\mathrm{PM}_{10}}-50.7$. The present study was conducive to understanding the distribution of $\mathrm{PM}_{25}$ and its correlation with other five pollutants of Xi'an. It would supply important support for the targeted controlling approach of fog and haze.

\section{Acknowledgements}

The work was supported by the National Key R\&D Program of China (NO. 2016YFC0700503) and the Special Research Project of Educational Commission of Shaanxi Province of China (No. 17JK0467).

\section{Conflict of Interest}

The authors declare no conflict of interest.

\section{References}

1. FILONCHYK M., YAN H.W., LI X.J. Temporal and spatial variation of particulate matter and its correlation with other criteria of air pollutants in Lanzhou, China, in spring-summer periods. Atmospheric Pollution Research. $9(6), 111,2018$.

2. ZHOU Q.L., WANG C.X., FANG S.J. Application of geographically weighted regression (GWR) in the analysis of the cause of haze pollution in China. Atmospheric Pollution Research. 10 (2), 840, 2019.

3. POZZER A., BACER S., DE ZOLT SAPPADINA S., PREDICATORI F., CALEFFI A. Long-term concentrations 
of fine particulate matter and impact on human health in Verona, Italy. Atmospheric Pollution Research. 10 (3), 737, 2019.

4. LIU L., LIU Y.S., WEN W., LIANG L.L., MA X., JIAO J., GUO K. Source Identification of Trace Elements in $\mathrm{PM}_{25}$ at a Rural Site in the North China Plain. Atmosphere. 11 (2), $1,2020$.

5. CHEN Q., LUO X.S., CHEN Y., ZHAO Z., HONG Y.W., PANG Y.T., HUANG, W.J., WANG Y., JIN L. Seasonally varied cytotoxicity of organic components in $\mathrm{PM}_{25}$ from urban and industrial areas of a Chinese megacity. Chemosphere. 230, 426, 2019.

6. FAN X.Y., GAO J.F., PAN K.L., LI D.C., DAI H.H., LI $\mathrm{X}$. More obvious air pollution impacts on variations in bacteria than fungi and their co-occurrences with ammonia-oxidizing microorganisms in $\mathrm{PM}_{25}$. Environmental Pollution. 251, 677, 2019.

7. ALGHAMDI M.A. Characteristics and Risk Assessment of Heavy Metals in Airborne PM $_{10}$ from a Residential Area of Northern Jeddah City, Saudi Arabia. Polish Journal of Environmental Studies. 25 (3), 939, 2016.

8. IARC. Outdoor air pollution a leading environmental cause of cancer deaths. Technical Report. International Agency for Research on Cancer. 2013

9. GUAITA R., PICHIULE M., MATE T., LINARES C., DIAZ J. Short-term of particulate matter $\left(\mathrm{PM}_{25}\right)$ on respiratory mortality in Madrid. International Journal of Environmental Health Research. 21 (4), 261, 2011.

10. EPA. National ambient air quality standards. US. 2015.

11. ZHU Z.Y., LI B., ZHAO Q.Y., XIA S.J., LI L. A Review and Outlook of the Research and Pollution Control on $\mathrm{PM}_{25}$ in Domestic and Overseas. Environmental Science and Technology. 26 (1), 72, 2013.

12. GB3095-2012. Ambient air quality standards. China Environmental Science Press. 2012.

13. JGJ/T 309-2013. The Standard of the measurement and evaluation for efficiency of building ventilation. Ministry of Housing and Urban-Rural Development of thePeople's Republic of China. 2013.

14. ZHANG L. The Meteorological Characteristics Effecting Concentration of $\mathrm{PM}_{10}$ and $\mathrm{PM}_{2.5}$ in Yanta District of Xi an. Xi'an: Xi'an University of Architecture and Technology. 2015.

15. ZERI M., LYRA G.B. Spatiotemporal analysis of particulate matter, sulfur dioxide and carbon monoxide concentrations over the city of Rio de Janeiro, Brazil. Meteorology and Atmospheric Physics. 113 (3-4), 149, 2011.

16. ZHOU Q.L., WANG C.X., FANG S.J. Application of geographically weighted regression (GWR) in the analysis of the cause of haze pollution in China. Atmospheric Pollution Research. 10 (2), 840, 2019.

17. WANG M.S., CAO J.L., GUI C.L., XU Z.F., SONG D.Y. The Characteristics of Spatiotemporal Distribution of PM2.5 in Henan Province, China. Polish journal of environmental studies. 26 (6), 2789, 2017.

18. ZHANG X., FAN Y.S., TIAN G.J., WANG H., ZHANG H.L., XIE W. Influence of Fiber Diameter on Filtration Performance of Polyester Fibers. Thermal Science. 23 (4), 2294, 2019

19. ZHANG X., FAN Y.S., WANG H., ZHANG J.X., WEI S.X., TIAN G.J., XIE W. Experimental study on the structure and properties of modified nonwoven filter fibers by impregnation with carbon black. Journal of Engineered Fibers and Fabrics. 15, 4, 2020.
20. TURKYILMAZ A., SEVIK H., CETIN M., AHMAIDA SALEH E.A. Changes in Heavy Metal Accumulation Depending on Traffic Density in Some Landscape. Polish journal of environmental studies. 27 (5), 2281, 2018.

21. CETIN M., SEVIK H. Change of air quality in Kastamonu city in terms of particulate matter and $\mathrm{CO} 2$ amount. Oxidation Communications. 39 (4), 3399, 2016.

22. ARICAK B., CETIN M., ERDEM R., SEVIK H., COMETEN H. The Usability of Scotch Pine (Pinus sylvestris) as a Biomonitor for Traffic-Originated Heavy Metal Concentrations in Turkey. Polish Journal of Environmental Studies, 29 (2), 1055, 2020.

23. CETIN M., SEVIK H., SAAT A. Indoor Air Quality: the Samples of Safranbolu Bulak Mencilis Cave. Fresenius Environmental Bulletin, 26 (10), 5968, 2017.

24. CETIN M. A Change in the Amount of $\mathrm{CO} 2$ at the Center of the Examination Halls: Case Study of Turkey. Studies on Ethno-Medicine, 10 (2), 152, 2016.

25. CETIN M., SEVIK H. Measuring the Impact of Selected Plants on Indoor $\mathrm{CO}_{2}$ Concentrations. Polish Journal of Environmental Studies, 25 (3), 977, 2016.

26. LI W.F., BAI Z.P., LIU A.X., CHEN J., CHEN L. Characteristics of Major $\mathrm{PM}_{25}$ Components during Winter in Tianjin, China. Aerosol and Air Quality Research. 9 (1), $114,2009$.

27. WANG J., HU Z.M., CHEN Y.Y., CHEN Z.L., XU S.Y. Contamination characteristics and possible sources of $\mathrm{PM}_{10}$ and $\mathrm{PM}_{2.5}$ in different functional areas of Shanghai, China. Atmospheric Environment. 68, 224, 2013.

28. LAI S.C., ZHAO Y., DING A.J., ZHANG Y.Y., SONG T.L., ZHENG J.Y., HO K.F., LEE S.C., ZHONG L.J. Characterization of $\mathrm{PM}_{25}$ and the major chemical components during a 1-year campaign in rural Guangzhou, southern China. Atmospheric Research. 167, 211, 2016.

29. DAI C.H., HUANG S.J., PENG H., YI K.X., ZHOU Y.Y., QIN P.F. Particulate pollution status and its characteristics during 2015-2016 in Hunan, China. Atmospheric Pollution Research. 10 (3), 745, 2019.

30. HJ633-2012. Technical Regulation on Ambient Air Quality Index (on trial). China Environmental Science Press. 2012.

31. HJ663-2013. Technical regulation for ambient air quality assessment (on trial). China Environmental Science Press. 2013.

32. ZHU C.L., LI X.Q., LI F.Y. Analysis on variation trends and related features of concentration of main air pollution in Xi'an. Environmental Engineering. 35 (11), 107, 2017.

33. ZHANG H.L. Experimental Study of Filters of Different Grades on Outdoor Airborne Particulate Matter. Xi'an, Xi'an University of Architecture and Technology. 2018.

34. ZHANG F. Re-analysis and evaluation of atmospheric carbon dioxide $\left(\mathrm{CO}_{2}\right)$, methane $\left(\mathrm{CH}_{4}\right)$ and carbon monoxide (CO) at Mount Waliguan,China. Beijing, University of Chinese Academy of Sciences. 2011.

35. LUO Y.P., CHEN Y., DAI C.H., GUO H., LIU M.J., JIN H.H., ZHOU X.T. Correlation Analysis of Concentrations of $\mathrm{PM}_{25}$ and $\mathrm{NO}_{2}$ in City Ambient Air. Environmental Science and Management. 39 (10), 71, 2014.

36. JIANG J., ZHA Y., LI L. Simulation analysis of atmospheric $\mathrm{SO}_{2}$ contributions from different regions in China. Atmospheric Pollution Research. 10, 919, 2019.

37. WANG M.S., CAO J.L., GUI C.L., XU Z.F., SONG D.Y. The Characteristics of Spatiotemporal Distribution of PM2.5 in Henan Province, China. Polish journal of environmental studies, 26 (6), 2789, 2017. 